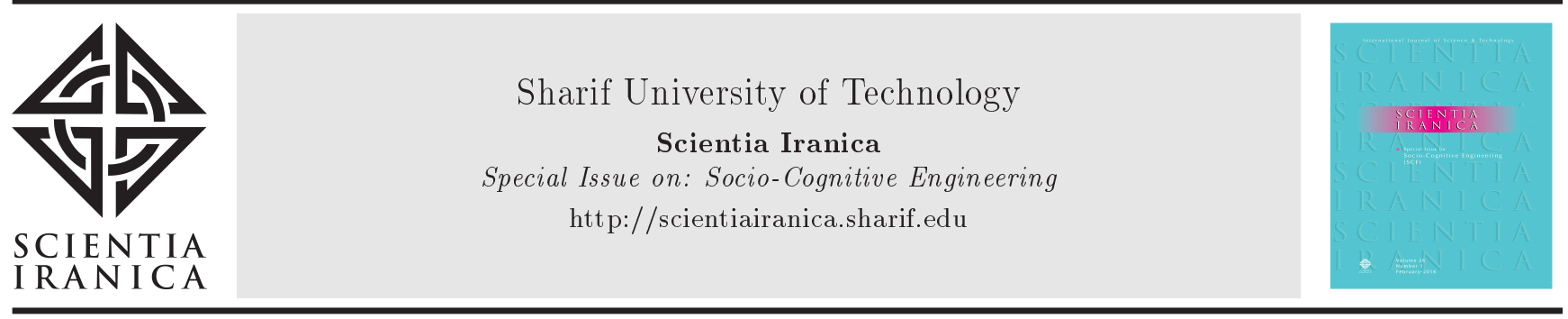

Research Note

\title{
Acceptance of online social networks as technology-based education tools among higher institution students: Structural equation modeling approach
}

\author{
M.A. Al-Sharafi*, M.E. Mufadhal, N.A. Sahabudin, and \\ R.A. Arshah \\ Faculty of Computer Systems \& Software Engineering, Universiti Malaysia Pahang Lebuhraya Tun Razak, 26300 Gambang, Pahang, \\ Malaysia.
}

Received 7 August 2018; received in revised form 15 October 2018; accepted 29 October 2018

\author{
KEYWORDS \\ Online social \\ networks; \\ Technology \\ acceptance model; \\ Emerging technology- \\ based education; \\ Social influence; \\ Perceived enjoyment; \\ Structural equation \\ modeling.
}

\begin{abstract}
Educational institutions are adopting Online Social Networks (OSNs) to support learning activities in university campuses. However, implementing a new technology requires identifying and assessing the factors that influence users' acceptance of a new technology. Accordingly, this method enables the critical prediction of the success or failure of a new technology. This study aims to identify the factors that influence a student's acceptance of OSNs as a learning tool by developing a research model based on the identified factors and on the technology acceptance model. The proposed model was further validated by employing online survey data collected from 537 students of the University Malaysia Pahang. Thereafter, structural equation modeling was utilized to analyze the collected data. Findings provide significant implications and considerable value for higher education institutions in adopting improved strategies for implementing OSNs as a learning tool.

(C) 2019 Sharif University of Technology. All rights reserved.
\end{abstract}

\section{Introduction}

Over the years, Online Social Networks (OSNs) have emerged as one of the applications that has been deployed as a result of the development of Web $2.0[1,2]$. Web 2.0 provides tools that facilitate communication, collaboration, and sharing of content among users through the Internet [3]. OSNs provide users with the capability to create groups and disseminate infor-

*. Corresponding author. Tel.: +601111303694

E-mail addresses: ma_shrafi@yahoo.com (M.A. Al-Sharafi); mufadhel@gmail.com (M.E.Mufadhal); azida@ump.edu.my (N.A. Sahabudin); ruzaini@ump.edu.my (R.A. Arshah)

doi: $10.24200 /$ sci.2018.51570.2256 mation among other users with similar interests [4]. However, a few studies, such as Wang et al. [4], have stated that OSNs face several issues associated with the adoption process. Hence, the learning procedures should be improved in university campuses.

Furthermore, OSNs can be utilized as a technology-based education tool to support academic activities, such as sharing of learning materials and dissemination of class announcement [5]. OSNs can also be referred to as a green or eco-friendly practice because of enabling students to submit their progress report online, thereby reducing paper usage [6]. Therefore, OSNs are considered as an effective tool for facilitating virtual discussions between teachers and students [7]. Thus, an increasing number of universities are adopting OSNs as an emerging technology-based 


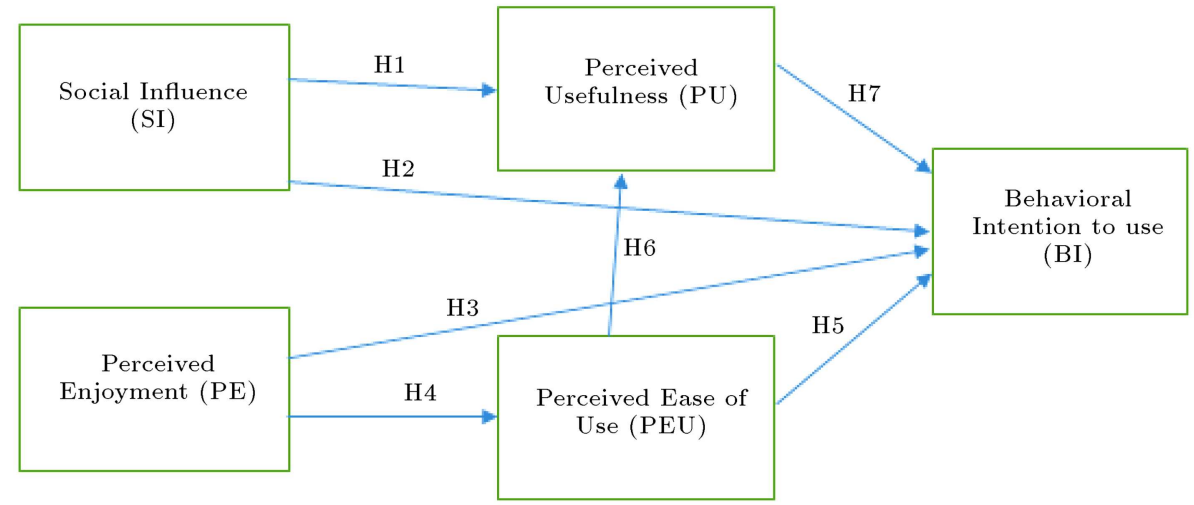

Figure 1. Proposed research model.

tool in their daily institutional activities, particularly given that students use OSNs to support their learning [8]. Evidently, universities believe that OSNs can enable students to gain access to learning materials, collaborate, discuss, and receive information on class schedule [9]. However, the adoption of a technology, such as OSNs, faces factors that affect end users' acceptance of such a technology [10]. Hence, the factors that influence the acceptance of OSNs should be identified to facilitate the assessment and prediction of the success of adopting new OSNs in universities. Moreover, prior studies [11-20] have revealed that a limited number of research studies have analyzed the significance of the factors that influence students' intention to use OSNs as learning tools.

This study aims to address the following research objectives:

- To identify the factors that affect and motivate students' acceptance of OSNs as learning-based tools;

- To develop a research model to analyze students' intention to use OSNs;

- To validate the proposed model using the structural equation modeling (SEM) approach.

The findings of this study facilitate the confirmation of the factors that motivate students to accept and use OSNs as learning tools. Moreover, our results have implications toward assisting lecturers in the effective deployment of OSN tools in the education context $[12,21]$. The remainder of this paper is organized as follows. Section 2 presents the model development and hypotheses. Section 3 discusses the research methodology. Section 4 presents the findings and discussion. Lastly, Section 5 presents the conclusion, limitations, and future research.

\section{Model and hypotheses development}

To accomplish the first research objective, Section 2 presents the identified factors that influence and moti- vate students' acceptance of OSNs as learning-based tools. These factors are derived from prior studies (see Table 1) and are clustered as Social Influence (SI), Perceived Enjoyment (PE), Perceived Usefulness (PU), and Perceived Ease of Use (PEU) (see Figure 1).

Table 1 presents a review of the related studies. The derived factors and associated hypotheses that influence students' adoption of OSNs are described below.

\subsection{Social Influence (SI)}

The SI variable measures the perception of how individuals are influenced by people who are important to them. The influence of these people determines the behavior of the students in using OSNs [24]. SI is considered the main determinant of the behavior intention to use [25]. Thus, the following hypotheses are proposed:

- H1: SI of using OSNs as a learning tool has a significant influence on its $\mathrm{PU}$;

- H2: SI of using OSNs as a learning tool has a significant influence on BI.

\subsection{Perceived Enjoyment (PE)}

$\mathrm{PE}$ is also known as perceived playfulness [11] and measures the degree by which users believe that the use of OSNs will result in certain pleasure and enjoyment [11]. The following hypotheses are proposed on the basis of the preceding definition:

- H3: PE of using OSNs as a learning tool has a significant influence on its PEU;

- H4: The PE of using OSNs as a learning tool has a significant influence on BI.

\subsection{Perceived Usefulness (PU) and Perceived Ease of Use (PEU)}

Prior studies [11-13] have revealed that PU has a positive influence on PEU. Thus, the easier, simpler, and more user-friendly the activities are for a social media user, the easier it is for him/her to adopt OSNs as a learning tool [26]. 
Table 1. Review of related works.

\begin{tabular}{|c|c|c|c|}
\hline Author(s) & $\begin{array}{l}\text { Model/technique } \\
\text { applied }\end{array}$ & Independent variables & Dependent variables \\
\hline$[11]$ & $\begin{array}{l}\text { TAM } \\
\text { PCA } \\
\text { SEM }\end{array}$ & $\begin{array}{l}\text { PU, PEU, SN, perceived playfulness, Internet } \\
\text { reliability and speed }\end{array}$ & $\begin{array}{l}\text { Adoption and usage } \\
\text { behavior of social media }\end{array}$ \\
\hline$[12]$ & $\begin{array}{l}\text { TAM } \\
\text { SEM }\end{array}$ & PU, PEU & $\begin{array}{l}\text { Intention to use social } \\
\text { networks }\end{array}$ \\
\hline$[22]$ & $\begin{array}{l}\text { Spearman's rank } \\
\text { correlation coefficient }\end{array}$ & $\begin{array}{l}\text { Experience in using OSNs, perceived social } \\
\text { presence; intensity of using OSNs }\end{array}$ & $\begin{array}{l}\text { Attitude of using OSNs } \\
\text { for academic purposes. }\end{array}$ \\
\hline$[13]$ & $\begin{array}{l}\text { TAM } \\
\text { SEM }\end{array}$ & PE, PU, PEU, SI & $\begin{array}{l}\text { Intention to use Twitter } \\
\text { as a source of } \\
\text { information }\end{array}$ \\
\hline [23] & $\begin{array}{l}\text { TAM } \\
\text { SEM }\end{array}$ & User attitude, PU, PEU, BI & $\begin{array}{l}\text { YouTube adaption as a } \\
\text { learning resource }\end{array}$ \\
\hline$[14]$ & $\begin{array}{l}\text { TAM } \\
\text { T-test } \\
\text { Regression }\end{array}$ & PU, PEU, collaborative learning, and engagement & $\begin{array}{l}\text { Intention to use social } \\
\text { media to improve } \\
\text { academic performance }\end{array}$ \\
\hline$[15]$ & $\begin{array}{l}\text { TAM and DOI. } \\
\text { SEM }\end{array}$ & $\begin{array}{l}\text { PU, PEU, SI, facilitating conditions, group } \\
\text { identity, social relation, linking jobs, daily } \\
\text { activities, cooperation, and sharing material }\end{array}$ & $\begin{array}{l}\text { Intention to use } \\
\text { Facebook as a virtual } \\
\text { classroom }\end{array}$ \\
\hline$[16]$ & $\begin{array}{l}\text { Correlational and } \\
\text { Reliability T-test } \\
\text { Regression }\end{array}$ & $\begin{array}{l}\text { Social acceptance, acculturation, and Facebook } \\
\text { usage intensity }\end{array}$ & Academic performance \\
\hline$[17]$ & $\begin{array}{l}\text { TAM } \\
\text { IS success model } \\
\text { SEM } \\
\text { Path analysis }\end{array}$ & $\begin{array}{l}\text { Educational quality, service quality, technical } \\
\text { system quality, content and information quality, } \\
\text { PEU, PU }\end{array}$ & $\begin{array}{l}\text { Satisfaction and } \\
\text { intention of using e- } \\
\text { learning }\end{array}$ \\
\hline$[18]$ & TAM & $\begin{array}{l}\text { PU, PEU, SI, computer self-efficacy, system } \\
\text { design and feature, PE, perceived mobility value, } \\
\text { perceived interactivity }\end{array}$ & $\begin{array}{l}\text { Intention to use social } \\
\text { networks }\end{array}$ \\
\hline [19] & SEM & $\begin{array}{l}\text { PU, P, social relations, SI, facilitating conditions, } \\
\text { community identify, daily activity, work related, } \\
\text { communication, collaboration, material/resource } \\
\text { sharing }\end{array}$ & \\
\hline [20] & TAM & PU, PEU, SN & $\begin{array}{l}\text { Intention to use social } \\
\text { media. }\end{array}$ \\
\hline
\end{tabular}

Note: TAM: Technology Acceptance Model; PCA: Component analysis; SEM: Structural Equation Modeling; DOI: Diffusion Of Innovations; PU: Perceived Usefulness; PEU: Perceived Ease of Use; and SN: Subjective Norm. 
The following hypotheses are proposed on the basis of the preceding statement:

- H5: OSNs' PEU as a learning tool has a significant influence on $\mathrm{BI}$;

- H6: OSNs' PEU as a learning tool has a significant influence on PU;

- H7: PU of using OSNs as a learning tool has a significant influence on BI.

The research model is developed (see Figure 1) on the basis of the discussions in Sections 2.1 to 2.3.

Figure 1 depicts the proposed research model that aims to accomplish the second research objective.

\section{Research Methodology}

To achieve the third research objective, Section 3 aims to validate the proposed research model by utilizing the data collected from a self-administered questionnaire given purposively to select students from different faculties of the University Malaysia Pahang (UMP) located in eastern Malaysia. The questionnaire comprises 22 questions that are based on the identified variables from prior studies (see Table 1).

The sample for this study includes students with at least two semesters of experience in using a Learning management system (LMS) platform (i.e., KALAM) and are members of Facebook groups for students to interact with lecturers. Accordingly, 537 participants gathered in the first and second semesters of the academic year 2017-2018. Data were collected from different faculties of UMP to avoid potential response bias. In addition, to check non-bias statistically, this study followed the recommendation proposed by [27] through comparing early response (first 100) and late response (last 100). The findings of the one-way
ANOVA test indicate that there is no significant difference between early and late respondents because Pvalue is more than 0.05 (see Table 2 ).

The survey questionnaire was divided into three parts: a cover letter, a demographic section, and questions based on the identified factors and associated items. The cover letter was provided to all of the participants to clarify the objectives of this study and the definitions of a few OSNs terms. Thereafter, informed consent was obtained from the participants to ensure that their privacy rights would be respected and the participants' responses would remain anonymous. The demographic part of the questionnaire consists of the information related to the respondents, such as gender, age group, program, faculty, and experience in using OSNs. The last section of the survey consists of questions to rate the identified factors (i.e., PE, PU, PEU, SI, and BI) based on a 5-point Likert scale (see Table 3).

\section{Findings and discussion}

\subsection{Measurement model}

The SEM approach was employed to validate the proposed model to achieve the third research objective. Moreover, Smart PLS 3 was used to analyze the questionnaire data. Accordingly, Composite Reliability (CR) was utilized to assess the reliability value of the model variables, in which the $\mathrm{CR}$ values above 0.70 were considered satisfactory, while values between 0.60 and 0.70 were acceptable [29]. The results presented in Table 4 show that all the CR values for the variables were above 0.70 , thereby indicating good internal consistency reliability. Moreover, the factor loading and Average Variance Extracted (AVE) were checked to assess the convergent validity of the measurement model. The results in Table 4 and Figure 2 reveal

Table 2. One-way ANOVA for non-bias.

\begin{tabular}{|c|c|c|c|c|c|}
\hline \multicolumn{6}{|c|}{ ANOVA test for faculty (first 100 respondents) } \\
\hline & Sum of squares & df & Mean square & $\mathbf{F}$ & Sig. \\
\hline Between groups & 7701.954 & 4 & 1925.489 & 2.419 & 0.054 \\
\hline Within groups & 75623.046 & 95 & 796.032 & & \\
\hline Total & 83325.000 & 99 & & & \\
\hline \multicolumn{6}{|c|}{ ANOVA test for faculty (last 100 respondents) } \\
\hline & Sum of squares & df & Mean square & $\mathbf{F}$ & Sig. \\
\hline Between groups & 7001.125 & 4 & 1750.281 & 2.179 & 0.077 \\
\hline Within groups & 76323.875 & 95 & 803.409 & & \\
\hline Total & 83325.000 & 99 & & & \\
\hline
\end{tabular}


Table 3. Measurement variables and associated items.

\begin{tabular}{|c|c|c|c|}
\hline Variables & Code & Items to measure variables & Sources \\
\hline \multirow[t]{5}{*}{$\mathrm{PE}$} & PE1 & I experience great pleasure when using OSNs as a learning tool. & {$[13]$} \\
\hline & PE2 & I feel satisfied when I use OSNs as a learning tool. & \\
\hline & PE3 & I feel pleasure when I use OSNs as a learning tool. & \\
\hline & $\mathrm{PE} 4$ & I find enjoyment when I use OSNs as a learning tool. & \\
\hline & PE5 & Overall, OSNs is fun as a learning tool. & \\
\hline \multirow[t]{4}{*}{ PU } & PU1 & Using OSNs as a learning tool helps me to complete my assignments more quickly. & {$[3,13]$} \\
\hline & PU2 & Using OSNs as a learning tool increases my learning achievement. & \\
\hline & PU3 & Using OSNs as a learning tool makes it easier for me to better understand my courses. & \\
\hline & PU4 & Overall, OSNs as a learning tool is useful in my university study. & \\
\hline \multirow[t]{4}{*}{ PEU } & PEU1 & I find it easy to use OSNs to use as a learning tool. & {$[3,13,28]$} \\
\hline & PEU2 & It is easy for me to become skillful in using OSNs as a learning tool. & \\
\hline & PEU3 & OSNs is flexible to interact with & \\
\hline & PEU4 & Overall, OSNs as a learning tool is easy for me to use. & \\
\hline \multirow[t]{5}{*}{ SI } & SI1 & People who are important to me think that I should use OSNs as a learning tool. & {$[13]$} \\
\hline & SI2 & $\begin{array}{l}\text { Students who use OSNs as a learning tool enjoy greater recognition from teachers } \\
\text { than those who do not use it }\end{array}$ & \\
\hline & SI3 & $\begin{array}{l}\text { Students who use OSNs as a learning tool at university enjoy better grades } \\
\text { than those who do not use it. }\end{array}$ & \\
\hline & SI4 & People whose opinion I value prefer me to use OSNs as a learning tool. & \\
\hline & SI5 & Overall, use of OSNs as a learning tool will improve my social image in the college. & \\
\hline \multirow[t]{4}{*}{ BI } & BI1 & I intend to begin/continue use OSNs to interact with colleagues and lecturers. & {$[11,13]$} \\
\hline & $\mathrm{BI} 2$ & I will continue to use OSNs as a learning tool. & \\
\hline & BI3 & I will strongly recommend use of OSNs as a learning tool to others. & \\
\hline & $\mathrm{BI} 4$ & Overall, I intend to continue using OSNs as a learning tool. & \\
\hline
\end{tabular}

that the factor loading ranged from 0.780 to 0.930 , thereby exceeding the recommended threshold value of 0.7 by Hair et al. [30]. Similarly, the AVE values for all constructs were above 0.5 and ranged between 0.6 and 0.8 for all constructs. In summary, the results presented in Table 4 and Figure 2 indicate that the measurement model has strong validity and acceptable reliability.

Figure 2 shows the results (loading, path coefficient, and $R^{2}$ ) of the measurement model.

\subsection{Structural analysis}

The SEM approach was also utilized to analyze the structural model through Partial Least Squares (PLS) regression analyses using Smart PLS 3. PLS was used to test the model hypotheses (i.e., H1 to H7; see Figure 1). The results of testing the hypotheses presented in Table 5 validate the proposed research model. Accordingly, Table 5 depicts the results of the validation, and shows that all hypotheses are supported because all $t$-values are above 1.96 and $p$-values are below 0.05 , as recommended by Hair et al. [30].

The results in Table 5 show that BI is one of the main endogenous constructs that was predicted by SI $(\beta=0.296), \operatorname{PE}(\beta=0.156), \operatorname{PEU}(\beta=0.305)$, and $\mathrm{PU}(\beta=0.206)$. The result suggests that the variables (PE, PEU, and PU) independently explain $72 \%$ of the variance of intention to use $\left(R^{2}=0.724\right)$. This result is analogous with prior studies, in which $R^{2}=0.506$ [13], $R^{2}=0.372$ [18], $R^{2}=0.67$ [17], and $R^{2}=0.53$ [31]. 
Table 4. Convergent validity.

\begin{tabular}{|c|c|c|c|c|}
\hline Construct & Items & Factor loading & $\begin{array}{l}\text { Average Variance } \\
\text { Extracted (AVE) }\end{array}$ & $\begin{array}{c}\text { Composite Reliability } \\
\text { (CR) }\end{array}$ \\
\hline \multirow[t]{4}{*}{ BI } & BI1 & 0.820 & 0.800 & 0.940 \\
\hline & $\mathrm{BI} 2$ & 0.900 & & \\
\hline & $\mathrm{BI} 3$ & 0.930 & & \\
\hline & $\mathrm{BI} 4$ & 0.920 & & \\
\hline \multirow[t]{5}{*}{$\mathrm{PE}$} & PE1 & 0.880 & 0.740 & 0.920 \\
\hline & PE2 & 0.890 & & \\
\hline & PE3 & 0.860 & & \\
\hline & PE4 & 0.880 & & \\
\hline & PE5 & 0.870 & & \\
\hline \multirow[t]{4}{*}{ PEU } & PEU1 & 0.890 & 0.770 & 0.940 \\
\hline & PEU2 & 0.840 & & \\
\hline & PEU3 & 0.820 & & \\
\hline & PEU4 & 0.900 & & \\
\hline \multirow[t]{4}{*}{$\mathrm{PU}$} & PU1 & 0.840 & 0.760 & 0.930 \\
\hline & PU2 & 0.890 & & \\
\hline & PU3 & 0.870 & & \\
\hline & PU4 & 0.880 & & \\
\hline \multirow[t]{5}{*}{ SI } & SI1 & 0.790 & 0.670 & 0.910 \\
\hline & SI2 & 0.840 & & \\
\hline & SI3 & 0.780 & & \\
\hline & SI4 & 0.880 & & \\
\hline & SI5 & 0.800 & & \\
\hline
\end{tabular}

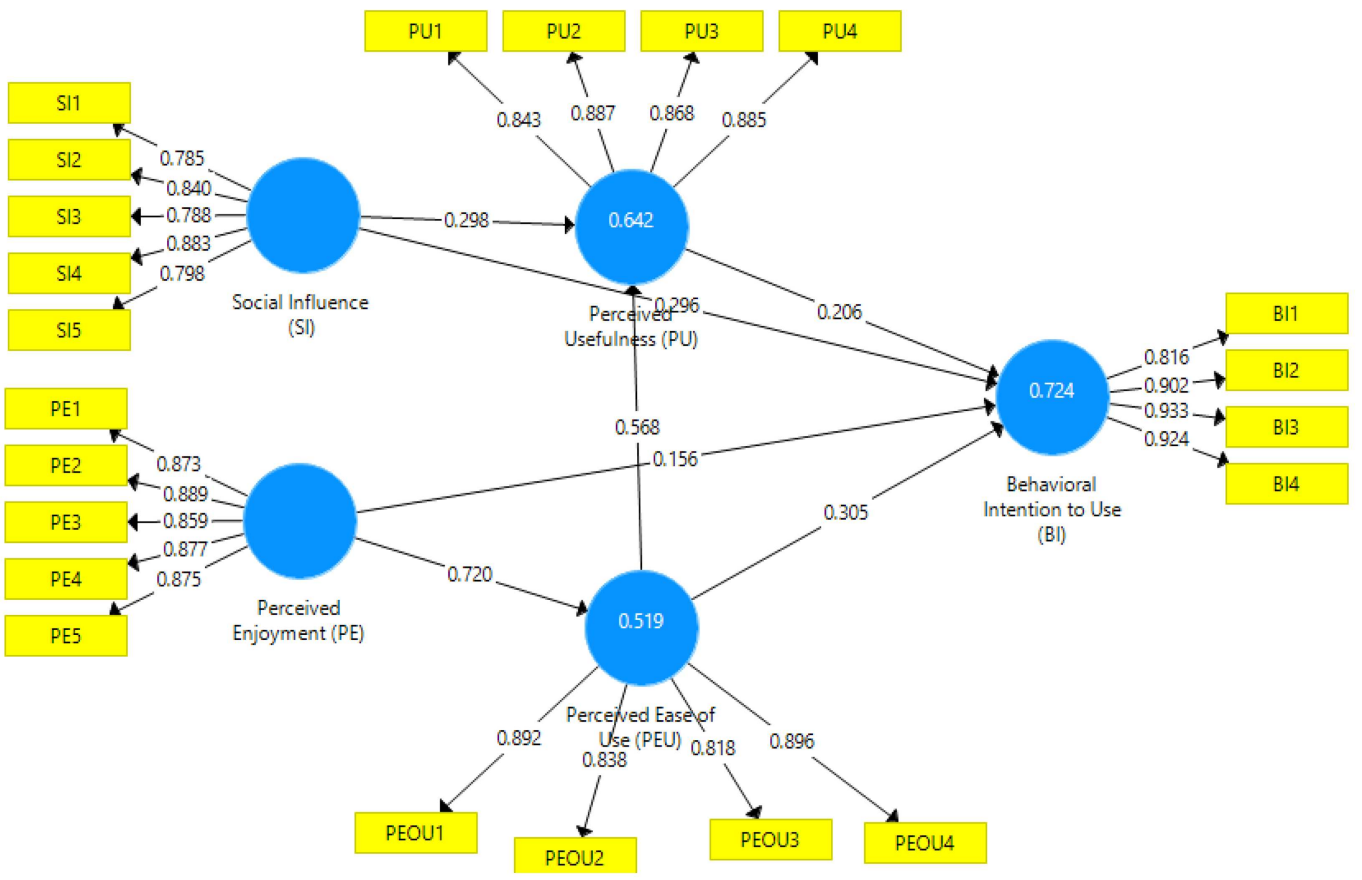

Figure 2. Measurement model results. 
Table 5. Hypothesis testing results.

\begin{tabular}{ccccccc}
\hline Hypothesis & Relationship & Std. Beta & Std. Error & $\boldsymbol{T}$ values & $\boldsymbol{P}$ values & Decision \\
\hline H1 & SI $->$ PU & 0.298 & 0.043 & 6.879 & 0.000 & Supported \\
H2 & SI $->$ BI & 0.296 & 0.044 & 6.710 & 0.000 & Supported \\
H3 & PE -> PEU & 0.720 & 0.029 & 24.655 & 0.000 & Supported \\
H4 & PE -> BI & 0.156 & 0.041 & 3.817 & 0.000 & Supported \\
H5 & PEU -> BI & 0.305 & 0.050 & 6.157 & 0.000 & Supported \\
H6 & PEU -> PU & 0.568 & 0.042 & 13.499 & 0.000 & Supported \\
H7 & PU -> BI & 0.206 & 0.050 & 4.087 & 0.000 & Supported \\
\hline
\end{tabular}

Our result indicates that $\mathrm{PU}$ is influenced by SI at $\beta=0.298$, thereby confirming $\mathrm{H} 1$. This result is similar to the results of [13]. Correspondingly, the path coefficient between SI and BI was determined to be significant at $\beta=0.296$. This finding supports $\mathrm{H} 2$ and is consistent with the findings of prior studies $[13,18,32,33]$. Furthermore, the survey data suggest that PEU is predicted by $\mathrm{PE}$ at $\beta=0.720$, thereby supporting H3. The evident reason for this result is that $\mathrm{PE}$ is the most significant variable that influences students' intention to adopt OSNs as a learning tool; this result is analogous with the results of prior $[13,18]$, where $\mathrm{PE}$ is also the most significant factor.

Moreover, our results suggest that PE influences $\mathrm{BI}$ at $\beta=0.156$, thereby indicating that PE supports H4. This result is consistent with the findings of $[14,34]$. Furthermore, the results in Table 5 indicate that PEU has the highest $\beta$ value of $\beta=0.305$, thereby suggesting that PEU is the high-performance construct that significantly influences an individual's intention toward adopting OSNs as a learning tool. Thus, $\beta$ value of PEU supports H5. This result is similar to those of prior studies. In particular, this study [35] stated that PEU had a positive effect on intention. However, this finding is inconsistent with the findings of [13] and [14], in which PEU does not significantly influence BI.

Moreover, our result indicated that PU was influenced by PEU with $\beta=0.568$, thereby confirming $\mathrm{H} 6$. This result is similar to those of $[13,14,18,32,35]$. In addition, the proposed result suggested that the path coefficient between $\mathrm{PU}$ and $\mathrm{BI}$ was determined to be significant at $\beta=0.206$, which is similar to the results presented in $[13,14]$. Therefore, H7 is supported.

\section{Conclusion, limitations, and future research}

This study developed a model to analyze the acceptance of OSNs as a learning tool by employing a survey to collect data from the students of UMP. Thereafter, the SEM approach using Smart PLS 3 was utilized to analyze the collected data. The results from the survey data validated the model hypotheses (H1H7). However, this study possessed a few limitations.
First, data were collected only from UMP students in Malaysia. Therefore, the findings of this study cannot be generalized to other universities. Moreover, the respondents might not have completed all the questionnaire items at once because the questionnaire was conducted online. The respondents may have browsed other websites while answering the questionnaire, thereby distracting and preventing them from focusing on the questions. This study did not address the negative aspects of adopting OSNs as a learning tool in educational institutions. Thus, future research should involve the analysis of the issues related to these negative aspects. In addition, the results of $R^{2}$ from this research for PEU are moderate, thereby suggesting that the correlation of the exogenous constructs of each variable is only partially explained. Therefore, the research model should be refined by including at least two exogenous constructs to further strengthen the research model.

Therefore, future researchers should conduct an explorative study by employing such methodologies as a focus group to identify other exogenous constructs for PEU. Accordingly, the acceptance of OSNs as a learning tool can be measured. Future studies can also extend our research to other geographical locations and obtain additional respondents to derive a substantially generalized result. However, despite the aforementioned limitations, this study provides implications that are beneficial for future researchers and academic institutions that seek to apply OSNs as a learning tool.

\section{Acknowledgment}

The authors gratefully acknowledge the Faculty of Computer Systems and Software Engineering, Universiti Malaysia Pahang as this research has been supported by the Research Grant No. RDU180310

\section{References}

1. Hew, K.F. and Cheung, W.S. "Use of Web 2.0 technologies in K-12 and higher education: The search for 
evidence-based practice", Educ. Res. Rev., 9, pp. 47-64 (2013).

2. Jabr, N.H. "Social networking as a tool for extending academic learning and communication", Int. J. Bus. Soc. Sci., 2(12) (2011).

3. Al-sharafi, M.A., Arsha, R.A., Abu-shanab, E., and Elayah, N. "The effect of security and privacy perceptions on customers' trust to accept internet banking services: An extension of TAM literature review", $J$. Eng. Appl. Sci., 11(3), pp. 545-552 (2016).

4. Wang, Q., Woo, H.L., Quek, C.L., Yang, Y., and Liu, M. "Using the Facebook group as a learning management system: An exploratory study", Br. J. Educ. Technol., 43(3), pp. 428-438 (2012).

5. Hamid, S., Waycott, J., Chang, S., and Kurnia, S. "Appropriating online social networking (OSN) activities for higher education: Two Malaysian cases", Chang. Demands, Chang. Dir. Proc. Ascilite Hobart, pp. 526-538 (2011).

6. Anthony Jnr, B., Abdul Majid, M., and Romli, A. "Case based reasoning for green information systems infusion and assimilation among IT professionals in university campuses", Sci. Iran., Special Issue on Socio-Cognitive Eng., 26(1) (2018).

7. Hajli, M., Bugshan, H., Lin, X., and Featherman, M. "From e-learning to social learning-a health care study", Eur. J. Train. Dev., 37(9), pp. 851-863 (2013).

8. Irwin, C., Ball, L., Desbrow, B., and Leveritt, M. "Students' perceptions of using Facebook as an interactive learning resource at university", Australas. J. Educ. Technol., 28(7), pp. 1221-1232 (2012).

9. Selwyn, N. "Social media in higher education", Eur. World Learn., pp. 1-10 (2012).

10. Şahin, H. and Topal, B. "Impact of information technology on business performance: Integrated structural equation modeling and artificial neural network approach", Sci. Iran., 25(3), pp. 1272-1280 (2018).

11. Dumpit, D.Z. and Fernandez, C.J. "Analysis of the use of social media in higher education institutions (HEIs) using the technology acceptance model", Int. J. Educ. Technol. High. Educ., 14(1), p. 5 (2017).

12. Elkaseh, A.M., Wong, K.W., and Fung, C.C. "Perceived ease of use and perceived usefulness of social media for e-learning in Libyan higher education: A structural equation modeling analysis", Int. J. Inf. Educ. Technol., 6(3), p. 192 (2016).

13. Al-Daihani, S.M. "Students' adoption of Twitter as an information source: An exploratory study using the technology acceptance model", Malaysian J. Libr. \& Inf. Sci., 21(3), pp. 57-69 (2016).

14. Al-rahmi, W.M., Othman, M.S., and Yusuf, L.M. "Social media for collaborative learning and engagement: Adoption framework in higher education institutions in Malaysia", Mediterr. J. Soc. Sci., 6(3 S1), p. 246 (2015).
15. Milošević, I., Živković, D., Arsić, S., and Manasijević, D. "Facebook as virtual classroom-social networking in learning and teaching among Serbian students", Telemat. Informatics, 32(4), pp. 576-585 (2015).

16. Ainin, S., Naqshbandi, M.M., Moghavvemi, S., and Jaafar, N.I. "Facebook usage, socialization and academic performance", Comput. \& Educ., 83, pp. 64-73 (2015).

17. Mohammadi, H. "Investigating users' perspectives on e-learning: An integration of TAM and IS success model", Comput. Human Behav., 45, pp. 359-374 (2015).

18. Al-Ammary, J.H., Al-Sherooqi, A.K., and Al-Sherooqi, H.K. "The acceptance of social networking as a learning tools at University of Bahrain", Int. J. Inf. Educ. Technol., 4(2), p. 208 (2014).

19. Sánchez, R.A., Cortijo, V., and Javed, U. "Students' perceptions of Facebook for academic purposes", Comput. \& Educ., 70, pp. 138-149 (2014).

20. Dhume, S.M., Pattanshetti, M.Y., Kamble, S.S., and Prasad, T. "Adoption of social media by business education students: Application of technology acceptance model (TAM)", in Technology Enhanced Education (ICTEE), 2012 IEEE International Conference on, pp. 1-10 (2012).

21. Mufadhal, M.E., Sahabudin, N.A., and Al-Sharafi, M.A. "Conceptualizing a model for adoption of online social networks as a learning tool", Advanced Science Letters, 24(10), pp. 7747-7750 (2018).

22. Lim, J. and Richardson, J.C. "Exploring the effects of students' social networking experience on social presence and perceptions of using SNSs for educational purposes", Internet High. Educ., 29, pp. 31-39 (2016).

23. Chintalapati, N. and Daruri, V.S.K. "Examining the use of YouTube as a learning resource in higher education: Scale development and validation of TAM model", Telemat. Informatics, 34(6), pp. 853-860 (2016).

24. Teo, T. "The impact of subjective norm and facilitating conditions on pre-service teachers' attitude toward computer use: A structural equation modeling of an extended technology acceptance model", J. Educ. Comput. Res., 40(1), pp. 89-109 (2009).

25. Choi, G. and Chung, H. "Elaborating the technology acceptance model with social pressure and social benefits for social networking sites (SNSs)", Proc. Am. Soc. Inf. Sci. Technol., 49(1), pp. 1-3 (2012).

26. Davis, F.D. "Perceived usefulness, perceived ease of use, and user acceptance of information technology", MIS Q., 13(3), pp. 319-340 (1989).

27. Lambert, D.M. and Harrington, T.C. "Measuring nonresponse bias in customer service mail surveys", J. Bus. Logist., 11(2), p. 5 (1990). 
28. Evans, C., Raymond Hackney, D., Rauniar, R., Rawski, G., Yang, J., and Johnson, B. "Technology acceptance model (TAM) and social media usage: an empirical study on facebook", J. Enterp. Inf. Manag., 27(1), pp. 6-30 (2014).

29. Nunnally, J.C. and Bernstein, I.H., Psychological Theory, New York, NY McGraw-Hill (1994).

30. Hair Jr, J.F., Hult, G.T.M., Ringle, C., and Sarstedt, M. "A primer on partial least squares structural equation modeling (PLS-SEM)", Sage Publications (2016).

31. Motaghian, H., Hassanzadeh, A., and Moghadam, D.K. "Factors affecting university instructors' adoption of web-based learning systems: Case study of Iran", Comput. \& Educ., 61, pp. 158-167 (2013).

32. Mouakket, S. "Factors influencing continuance intention to use social network sites: The Facebook case", Comput. Human Behav., 53, pp. 102-110 (2015).

33. Cheung, R. and Vogel, D. "Predicting user acceptance of collaborative technologies: An extension of the technology acceptance model for e-learning", Comput. Educ., 63, pp. 160-175 (2013).

34. Padilla-MeléNdez, A., Del Aguila-Obra, A.R., and Garrido-Moreno, A. "Perceived playfulness, gender differences and technology acceptance model in a blended learning scenario", Comput. \& Educ., 63, pp. 306-317 (2013).

35. Abbad, M.M., Morris, D., and De Nahlik, C. "Looking under the bonnet: Factors affecting student adoption of e-learning systems in Jordan", Int. Rev. Res. Open Distrib. Learn., 10(2), pp. 1-25 (2009).

\section{Biographies}

Mohammed A. Al-Sharafi is currently a research fellow at Faculty of Computer Systems and Software Engineering, Universiti Malaysia Pahang. He has MSc degree in Management Information System from Yarmouk University, Jordan. $\mathrm{He}$ is interested in research relating to cloud computing, internet banking, e-learning, and technology adoption.

Mokhtar Esmail Mufadhal received his MSc degree in Information \& Communication Technology from Faculty of Computer Systems and Software Engineering, Universiti Malaysia Pahang. $\mathrm{He}$ is interested in research relating to e-learning and business process management.

Noor Azida Sahabudin is currently a Senior Lecturer of Computer Science at the Faculty of Computer Systems and Software Engineering, Universiti Malaysia Pahang and received her $\mathrm{PhD}$ from University of Technology, Malaysia in 2015. Her research interest areas include e-learning, learning style, teaching style, and online social network.

Ruzaini Abdullah Arshah is currently an Associate Professor of Computer Science at Faculty of Computer Systems and Software Engineering (FSKKP), Universiti Malaysia Pahang, head, of Information Systems Research Group in FSKKP. His current research areas include database and information systems, knowledge management, business intelligence, information retrieval and social network. 